\title{
Food Security in the Face of Climate Change: Potential Roles of Underutilised Plant Species around Some Rural Homesteads in the Niger Delta
}

\author{
Elsie I. Hamadina1, Mohammed K. Hamadina ${ }^{2 *}$, Tamunobelema B. Solomon1 \\ ${ }^{1}$ Department of Crop and Soil Science, Faculty of Agriculture, University of Port Harcourt, Port Harcourt, Nigeria \\ ${ }^{2}$ Department of Soil Science Faculty of Agriculture University of Abuja, Abuja, Nigeria \\ Email: ^mkh259@gmail.com
}

How to cite this paper: Hamadina, E.I., Hamadina, M.K. and Solomon, T.B. (2018) Food Security in the Face of Climate Change: Potential Roles of Underutilised Plant Species around Some Rural Homesteads in the Niger Delta. Natural Resources, 9, 55-72.

https://doi.org/10.4236/nr.2018.93005

Received: January 30, 2018

Accepted: March 19, 2018

Published: March 22, 2018

Copyright $(9) 2018$ by authors and Scientific Research Publishing Inc. This work is licensed under the Creative Commons Attribution International License (CC BY 4.0).

http://creativecommons.org/licenses/by/4.0/

\section{(c) (i) Open Access}

\begin{abstract}
The food and nutrition status of the rural poor living in extreme deprivation are precarious in the event of catastrophic events occasioned by climate change. This study aimed at elaborating the potential roles of underutilised plant resources as sources of food in the face of climate change. A total of 37 plant species of different growth habits were sighted within the homesteads in the study communities. The commonest plant species around home provide food, medicine, cash, and cultural or spiritual purposes. These included Manihot esculenta (Cassava), Musa sapentium var. paradisiaca (Plantains) Musa sapentium (banana), Citrus sinensis (orange) and Elaeis guineensis (oil palm). Outside the home compounds to a considerable walking distance around each of the communities, a total of twenty seven (27) plant species and four habitat types (three terrestrial and one aquatic) were encountered, with Elaeis guineensis Jacq. being present in all the terrestrial ecotypes (forest, farmland and fallow regrowth). Many of the plant species encountered within the home compounds are edible; some are medicinal or have spiritual values, while most have multiple uses. Magnifera indica, Dacryodes edulis, Persea americana, Carica papaya, Chrysophyllum albidum and Ananas comosus, are cherished for their tasty fruits. Vernonia amygdalina, Telferia occidentalis, Ocimum brasilicum, Amaranthus hybridus and Gnetum africana are eaten vegetables in soups. Irvingia gabonensis (Ogbono) is valued for its seeds, which are used widely in preparing the Ogbono soup, which is widely popular across Nigeria. The kola nut (Cola nitida), bitter kola (Garcina kola) trees and yams (Dioscorea spp) serve significant spiritual/cultural roles amongst the local populace in the study area-they are always presented at ceremonies such as marriages, funerals and festivals. Plant species with mostly untapped potentials to supply
\end{abstract}


food and nutrients to the rural dwellers in the study area include breadfruit (Artocarpus cummunis), Avocado pear (Persia americana), Bush Mango (Irvingia gabonensis), Native pear (Dacryodes edulis), African Star Apple (Chrysophyllum albidum), and Raphia palm (Raphia hookeri) and Tropical Almond (Terminalia catappa). These plants are reported to contain variable amounts of dietary nutrients such as proteins, vitamins, minerals, fats, and fibre. Some of the plants have potentials to supply raw materials to sustain food and beverage industries.

\section{Keywords}

Climate Change, Food Security, Niger Delta, Home Gardens, Tropical Plants

\section{Introduction}

Almost 5 billion people across the globe are fed by only half a billion poor smallholder farmers, who are vulnerable to the impacts of climate change; with sub-Saharan Africa having the bulk of the smallholder farmers, where they produce $80 \%$ of the food [1] [2]. The livelihoods of these farmers are likely to suffer disproportionately in the face of even slight climatic changes, not to think of extreme changes [3] [4]. In the Niger Delta, like the rest of sub-Saharan Africa, homesteads and their immediate vicinities provide critical support to the livelihoods of the rural poor [5]. The homesteads and the adjoining areas are carefully managed and exploited, by the locals, as source of food, medicine, family nutrition, socio-cultural satisfaction and cash income [5] [6]. The homesteads in sub-Saharan Africa often harbour the home gardens (or compound farms) with diverse assemblage of wild and cultivated species of flora (and fauna), in an amorphous mixture [1] [7] [8], i.e., with no standard pattern of arrangements, except that they adjoin living homes [9]. In forested areas, the vicinity of the homestead also provides refuge to an array of wildlife species that are also exploited by the rural households as bush meat, which in recent times has become scarcer due to overexploitation as result of population boom [10] [11]. The homesteads and their immediate vicinities, therefore, provide food and nutrition security for the rural households, more so in difficult times such as during periods of disaster or ecological disruptions, such as floods, resulting from climate change [1] [7].

In general, the Niger Delta area is relatively free of significant natural disasters such as earthquakes, tsunamis, violent winds, wild fire, and landslides [12]. However, the Niger delta is not immune to man-made disasters, and quite prone to flooding due to its low-lying terrain coupled with heavy rainfall regime [13]. The communities evaluated in this study are found within the plains lying between Orashi River and Sombreiro River, which is prone to severe flash-floods. Recently (in 2012) the area experienced an unprecedented flood episode that led to the shutdown of oil and gas operations, and large-scale evacuation of entire 
haod households in the affected villages [13]. The flood, which lasted for a few months, submerged several villages, farmlands, and home gardens, which greatly demoralised the rural folks [13]. This scenario of flash-flood can be used to glimpse into the possible effects of climate change on rural communities in the Niger Delta, given the forecast that climatic change can cause similar events [14]. The local adaptation mechanisms, therefore, need to be explored in order to confront the severity of effects of climate change on the wellbeing of the smallholder farmers in future [15].

In the Niger Delta, petroleum hydrocarbon exploration activities (such as seismic surveys, land take as well as drilling and completion of exploratory/appraisal wells) commenced in the 1940s, but commercial production started in 1958 [16]. Ever since then, the exploration and production of petroleum hydrocarbon intensified, as the Delta proved prolific with continuous discovery of more oil fields and reserves (both onshore and offshore). There are over two hundred and fifty oil fields in the Niger Delta, resulting in the drilling of oil wells, and installation of hundreds of kilometres flow lines/pipeline, flow-stations, tank farms, and oil export terminals [16]. In addition, gas associated with the production of oil and gas has been routinely flared or vented into the atmosphere until recently (about a decade) when concerns about greenhouse gas emissions heightened. The petroleum hydrocarbon activities that result in ecological damages include discharge of obnoxious gases (through flaring, venting and exhaust emissions), oil/chemical spills, and improper waste handling/disposal. Social challenges are exacerbated by land take and the fallout of adverse ecological impacts, including climate change. In general, the rural inhabitants in the study are smallholder famers and resource poor, living on less than two dollars a day [17].

Due to concerns with the effects of gas flaring on the environment, including climate change; and the need to improve foreign earnings [18], Nigeria embarked on a liquefied natural gas (LNG) project. The aim was to harness the country's natural gas resources, leading to the establishment of the Nigerian Liquefied Natural Gas (NLNG) Plant at Bonny Island (Nigeria), with several gas processing plants to supply the processed gas input to the NLNG Plant. One of such plants is the Obite Gas Processing Plant, which is located in the study area -generally a rural setting with subsistent livelihoods. In addition to the gas processing plant, three captive power plants were installed, to valorise the gas that would otherwise be flared, to generate electricity [19]. The electricity generated is distributed to the communities in the study area, as part of "corporate social responsibility" and in a bid to satisfy the "host communities".

At the time of this study, the oil and gas facilities within the study area included 1) a Flow-station (where oil from clusters of well are pooled into a single stream), a Gas Treatment Centre, a Production Cluster, numerous oil and gas wells, and a network of pipelines of different sizes [19]. The ecological and social footprint of the oil and gas industry manifests as potpourri of adverse effects resulting from myriad of technical activities, influx of people in search of oppor- 
tunities, and accelerated "community development" precipitating as socio-cultural and ecological challenges [5] [20]. One of such effects is the expansion of built-up areas, changes in housing types, and destruction of flora around the homesteads to pave way for modern housing types. However, there is a dearth of information on the ecological resilience (in terms of floral diversity) of the areas around homesteads and their role as source of support to rural households in the communities in times of difficulty.

The nutritional status of Nigerian families is, perhaps, the most precarious in sub-Saharan Africa: one in three children is either stunted or malnourished, yet another one in five is said to be wasted [21]. To tackle this scenario, [21] reported that Nigeria, together with interested entities, has put in place elaborate intervention measures in the form of food fortification, supplementation and provision of therapeutic foods to the target population, to ensure food security. Despite spirited intervention by the Nigerian government and other interested entities, the nutritional insecurity of Nigerians does not seem to abate [21]. In general, it has been reported that, over the years, homestead gardens have supported the rural households with provision of additional income, as source of food and augmenting family finances [22]. The plants species found around the homesteads provide nutrients that help to combat "hidden hunger", i.e., nutrient deficiencies among the rural poor in many developing countries [22], especially during times food scarcities. In the Niger Delta, the area adjoining homesteads are utilised as home garden where selected perennial plant species are left to grow, and annual crops are also grown for food. In addition, the adjoining forests supply not only timber, but also non-timber resources such as medicine, spices, fruits, fibre, and other resources like dyes. Some species such as Garcinia cola, Kola spp, Chrysophyllum albidum and Irvingia gabonencis are exploited mainly for their fruits, but most also have multiples uses (e.g., medicine, fibre, and firewood). In the home gardens, several species are cultivated as for their leaves (vegetables), tubers, roots, corms, different parts that provide food to the folks. Yet, so many other species are tended for medicinal or spiritual values, including plants that are poisonous, which are used for nefarious reasons [5].

This study was undertaken to assess the floral diversity around rural homesteads in the Niger Delta to determine their roles as source of food (and family nutrition). The study has identified plants reported to have potentials as source of food, especially the underutilised ones, within the vicinity of homesteads of some communities in the Niger Delta. The study also ascertained the potentials of the underutilised plant species for ensuring food and nutrition security of people trapped between material poverty and ecological challenges resulting from hydrocarbon exploitation and compounded by climate change.

\section{Study Methodology/Approach}

\subsection{The Study Area}

The study area is characteristically a humid tropical environment, with mean 
annual rainfall in excess of $2500 \mathrm{~mm}$ lasting from April through November, with a short dry spell in-between; and ambient temperatures are above $25^{\circ} \mathrm{C}$ [13]. The soils in the study area are generally acidic, loamy sand and support luxurious native vegetation, although mostly in a disturbed state at the time of this study [19]. Apart from the built-up areas, the ecosystem of the area consists mainly of farmlands, fallow re-growth, swamp forests, secondary forests, and isolated patches primary forests (some are left as "restricted places" or spiritual sites).

\subsection{Characteristics of the Study Communities}

The study communities (8 nos.) are located in Ogba/Egbema/Ndoni Local Government Area (equivalent of a County) of Rivers State, in the oil producing Niger Delta region of Nigeria (Figure 1). The eight study communities are dispersed in about $50 \mathrm{~km}^{-1}$ area and they included Ogbogu, Akabuka, Obagi, Akabta, Obiyebe, Egita, Ede and Obite, which vary in size and complexities. The easily accessible communities or communities nearer to economic opportunities (Ogbogu, Akabuka, Obagi Ede and Obite) are more cosmopolitan with better quality of housing than the more remote ones (Akabta, Egita and Obiyebe) with less available opportunities (Plate 1). The communities belong to the Egi clan (made up of 16 constituent communities). For this study, eight communities were selected based on nearness to petroleum facilities, size, relative accessibility or

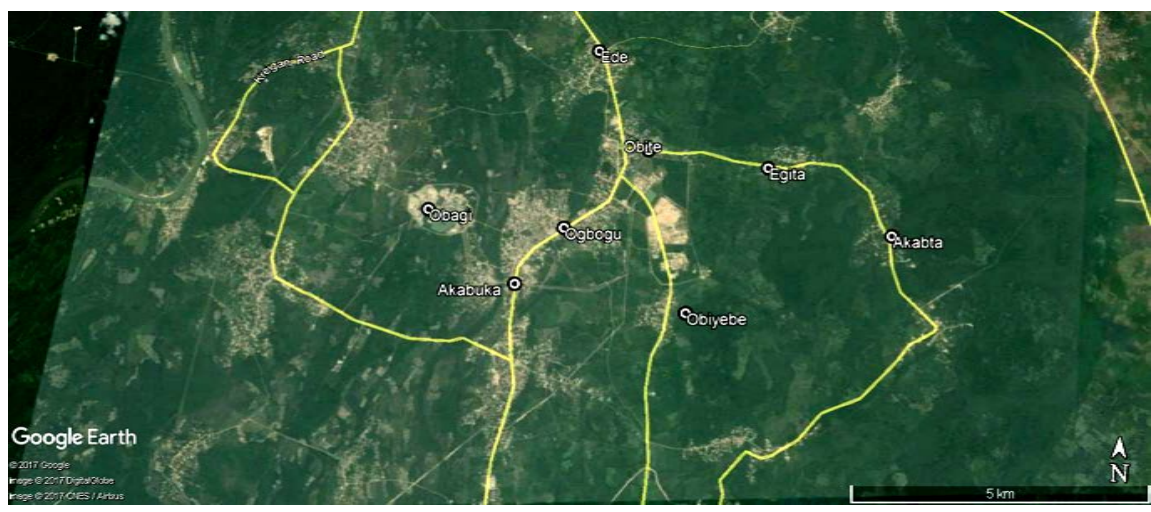

Figure 1. Map of study area showing survey communities.

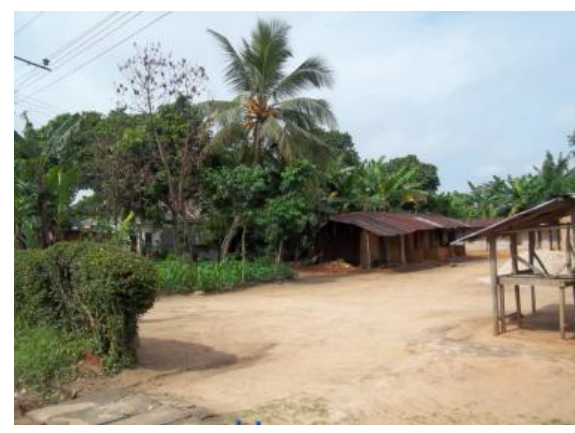

(a)

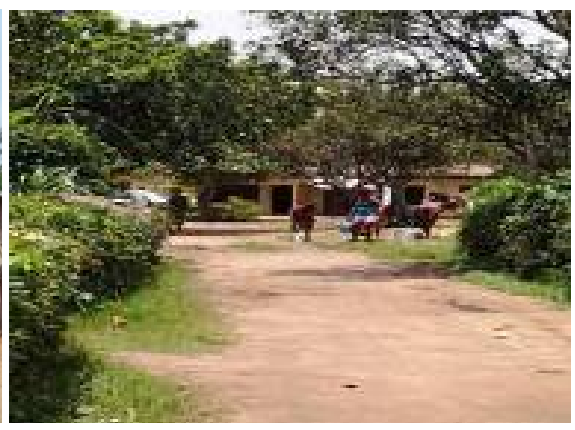

(b)

Plate 1 . The setting of the study communities showing a typical homestead (a) and a privileged homestead (b). 
remoteness. Thus, the eight communities encompass both rural and urbanising communities, as well as cosmopolitan and non-cosmopolitan ones.

Prior to production, exploration activities have been carried out leading to the discovery and commencement of commercial-scale production of crude oil in the Niger Delta. Consequently several oil production facilities were installed, upgraded or decommissioned as the need arose in the course of production and further exploration activities. This has inadvertently affected the ecological setting of the respective communities, as they dramatically transformed from sleepy rural setting to vibrant urban-like communities, with "modern" neighbourhoods springing up alongside rural homesteads [20].

\subsection{Survey, Identification and Evaluation of Plant Species}

Plant biodiversity was assessed using a mix of methods, which included field identification and sampling along transects, in each of the communities studied. Transects were cut across the various ecotypes found within and outside the immediate vicinity of homesteads. In addition to transect sampling, interviews were conducted with the local inhabitants using appropriate plant specimen. Samples of plants that were not identifiable in the field were brought to the herbarium of the University of Port Harcourt Nigeria, for proper identification. The keys contained in the standard reference book on the flora of West Africa by Hutchinson and Dalziel [23] [24] [25] [26] were used to identify plant specimens.

Each of the plant species identified during the field survey was evaluated for their future potentials by searching through several online databases of plant species and their uses around the world. Information on local uses of the identified plants was gleaned from published and unpublished sources, including consultations with local inhabitants of the study area. The consultations with local inhabitants were in the form of face-to-face interviews and focus group discussions (FGDs) with relevant interest groups in the respective communities.

\section{Results and Discussion}

\subsection{Plant Species Found in the Immediate Vicinity of Homesteads}

A checklist of plant species found inside, or within the immediate vicinity of homesteads in the various communities surveyed are shown in Table 1. Most of the plant species found are deliberately left for specific purposes, which include food, medicinal, cultural or spiritual purposes. Other purposes include sourcing of construction materials, tools making, and crafts, or as source of cash to satisfy mundane family needs like buying detergent or salt. The plant species that were most abundant, including Manihot esculenta (Cassava), Musa sapentium var. paradisiaca (Plantains) Musa sapentium (banana), Citrus sinensis (orange) and Elaeis guineensis (oil palm), were found in each of the eight communities surveyed (Table 1). Similarly, M. indica L. (Mango) and Dacryodes edulis L. ("native pear"), which are grown for their edible fruits, were found in homesteads of 
Table 1. Plant species found within the home gardens in 8 study communities in the Niger Delta.

\begin{tabular}{|c|c|c|c|c|}
\hline Scientific Name & Common Name & Family Name & Habit & Occurrence \\
\hline Abelmoschus esculentus (L.) Moench & Okro & Malvaceae & Herb & 3 \\
\hline Amaranthus hybridus (L.) & Spinach & Amaranthaceae & Herb & 1 \\
\hline Anacardium occidentale $\mathrm{L}$. & Cashew & Anacardiaceae & Shrub & 2 \\
\hline Ananas comosus (L.) Merr. & Pineapple & Bromeliaceae & Herb & 6 \\
\hline Annona muricata $\mathrm{L}$. & Soursop & Annonaceae & Shrub & 2 \\
\hline $\begin{array}{c}\text { Artocarpus communis J.R. Forst. \& } \\
\text { J.G.A. Forst. }\end{array}$ & Breadfruit & Moraceae & Tree & 2 \\
\hline Capsicum annuum $\mathrm{L}$. & Pepper & Solanaceae & Stout Herb & 2 \\
\hline Carica papaya L. & Pawpaw & Caricaceae & Tall Herb & 6 \\
\hline Chrysophyllum albidum G. Don & $\begin{array}{l}\text { White Star Apple } \\
\text { ("Udara") }\end{array}$ & Sapotaceae & Tree & 1 \\
\hline Citrus sinensis (L.) Osbeck & Orange & Rutaceae & Shrub & 8 \\
\hline Cocos nucifera $\mathrm{L}$. & Coconut & Arecaceae & Tree & 6 \\
\hline Cola nitida (Vent.) A. Chev. & Kolanut & Malvaceae & Tree & 3 \\
\hline Cymbopogon citratus DC. ex Nees & Lemon Grass & Poaceae & Grass & 1 \\
\hline Dacryodes edulis (G. Don) H.J. Lam & Native Pear (Ube) & Burseraceae & Tree & 7 \\
\hline Dioscorea cayenensis (L.) Lam. & Yellow Yam & Dioscoreaceae & Climber & 3 \\
\hline Dioscorea rotundata Poir. & White Yam & Dioscoreaceae & Climber & 2 \\
\hline Elaeis guineensis Jacq. & Oil Palm & Arecaceae & Tree & 8 \\
\hline Garcinia kola Heckel & Bitter Kola & Clusiaceae & Tree & 1 \\
\hline Gnetum africana (L.) Welw. & "Okazi" (native name) & Gnetaceae & Climber & 1 \\
\hline $\begin{array}{c}\text { Hevea brasiliensis } \\
\text { (Willd. ex A. Juss.) Müll. Arg }\end{array}$ & Rubber & Euphorbiaceae & Tree & 1 \\
\hline Ipomoea batatas (L.) Lam. & Sweet Potato & Convolvulaceae & Herb & 2 \\
\hline Irvingia gabonensis (O’Rorke) Baill & $\begin{array}{l}\text { Bush Mango } \\
\text { (“Ogbono") }\end{array}$ & Irvingiaceae & Tree & 5 \\
\hline Mangifera indica $\mathrm{L}$. & Mango & Anacardiaceae & Tree & 7 \\
\hline Manihot esculenta Crantz. & Cassava & Euphorbiaceae & Herb & 8 \\
\hline Musa paradisiaca L. & Plantain & Musaceae & Herb & 8 \\
\hline Musa sapientum $\mathrm{L}$. & Banana & Musaceae & Herb & 8 \\
\hline Ocimum brasilicum $\mathrm{L}$. & Sweet Basil & Lamiaceae & Herb & 6 \\
\hline Ocimum gratissimum $\mathrm{L}$. & Scent Leave & Lamiaceae & Herb & 5 \\
\hline Persea americana Mill. & Avocado & Lauraceae & Tree & 6 \\
\hline Psidium guajava $\mathrm{L}$. & Guava & Myrtaceae & Shrub & 5 \\
\hline Saccharum officinarum $\mathrm{L}$. & Sugar Cane & Poaceae & Grass & 6 \\
\hline Telfairia occidentalis Hook. f. & Fluted Pumpkin & Cucurbitaceae & Climber & 6 \\
\hline Terminalia catappa L. & Tropical Almond & Combretaceae & Tree & 1 \\
\hline Theobroma cacao L. & Cocoa & Malvaceae & Tree & 1 \\
\hline Vernonia amygdalina Del. & Bitter Leaf & Asteraceae & Shrub & 6 \\
\hline Xanthosoma mafaffa Schott & Cocoyam & Araceae & Herb & 6 \\
\hline Zea mays $\mathrm{L}$. & Corn & Poaceae & Grass & 5 \\
\hline
\end{tabular}

Occurence $=$ number of villages where species were encountered. 
seven of the communities surveyed. Apart from its edible fruits, mango leaves are also used to treat several ailments including fevers, stomach upsets and lethargy.

Nine other plant species were found in six of the communities surveyed in the Egi area of the Niger Delta. They include Persea americana, Cocos nucifera, Xanthosoma mafaffa, Vernonia amygdalina, Telfairia occidentalis, Saccharum officinarum, Ocimum brasilicum, Carica papaya and Ananas comosus. The species Persea americana (Avocado), which was recently introduced into the Niger Delta area, and aptly called "English Pear" by the natives, were sighted as lone trees growing in family compounds in the communities. Cocoyam (Xanthosoma mafaffa) is cultivated for its corm, while Bitter leaf (Vernonia amygdalina), Ugu (Telferia occidentalis), and Sweet Basil (Ocimum brasilicum), are grown as vegetables. Also, Saccharum officinarum (Sugarcane) and Cocos nucifera (coconut) are grown for their cane and fruits respectively.

Similarly, Ananas comosus L. (Pineaple) and C. papaya L. (Pawpaw) are planted for fruits and, especially in the case of mango, for medicinal purposes. Trees (Irvingia gabonensis, "bush mango" and Psidium guajava, Guava), corn (Zea mays) and the herb "Scent Leaves" (Ocimum gratissimum), were seen in five of the eight communities surveyed. The bush mangos and guava trees are grown for fruits, as well as for medicinal purposes. Scent leaves are used as vegetables for making soup and as spices for preparing pepper soup, while corn is consumed in different forms: roasted or boiled and eaten as snack or prepared in other forms such as gruel (pap).

Eight of the plant species were sighted in three, or less, communities, including economically important species such as Garcinia kola, Theobroma cacao, Harvea brasiliensis, Dioscorea spp, Anarcardium occidentalis, and Ipeoma batatas. Also, some species with underutilized potentials were also encountered in the study area and they include Chrysophyllum albidum, Artocarpus communis, Anonna muricate, Terminelia cartappa, Amaranthus hybridus and Gnetum africana. A turf of lemon grass was sighted in a compound in the study area, which appeared to be exotic to the area, but the owner was said to have planted it for medicinal purposes.

\subsection{Plant Species Found in Areas outside the Immediate Vicinity of Homesteads}

The plant species encountered in areas outside the immediate vicinity of homesteads, but within a walking distance, from the edge of homestead gardens to the forested areas are shown in Table 2. These areas comprised of diverse habitats, hence the plant species were segregated into the habitats where they were encountered. The plant habitats in question varied with communities but, basically, four habitat types were discerned including forests, fallow lands, riparian and aquatic.

A total of twenty seven (27) plant species were encountered in all the four habitats encountered, ten (10) of which occurred in more than one habitat. Three 
Table 2. Checklist of plant species found outside the immediate vicinity of homesteads on the periphery of villages studied.

\begin{tabular}{|c|c|c|c|c|c|c|c|}
\hline \multirow[b]{2}{*}{ Scientific Name } & \multirow[b]{2}{*}{ Common Name } & \multirow[b]{2}{*}{ Family Name } & \multirow[b]{2}{*}{ Habit } & \multicolumn{4}{|c|}{$\begin{array}{l}\text { Habitat Where Species } \\
\text { was Encountered }\end{array}$} \\
\hline & & & & Forest & $\begin{array}{l}\text { Fallow } \\
\text { Land }\end{array}$ & Riparian & Aquatic \\
\hline Albizia zygia (DC.) J.F.Macbr. & Albizia & Fabaceae & Tree & + & + & - & - \\
\hline Alchorneacordifolia (Schum. \& Thonn.) Müll. Arg. & Christmas Bush & Euphorbiaceae & Shrub & - & + & + & - \\
\hline Anthocleista vogelii Planch. & Cabbage Tree & Loganiaceae & Tree & + & - & + & - \\
\hline Anthonotha macrophylla P. Beauv. & Palissandre d'Afrique & Fabaceae & Tree & - & + & - & - \\
\hline Azolla pinnata R. Br. & Water Velvet & Azollaceae & Herb & - & - & - & + \\
\hline Calamus deeratus Mann \& Wendl. & Rattan & Palmaceae & Climber & - & - & + & - \\
\hline Calopogonium mucunoides Desv. & Calopo & Fabaceae & Creeper & + & + & - & - \\
\hline Chromolaena odorata L. & Siam Weed (Awolowo) & Asteraceae & Herb & - & + & - & - \\
\hline Combretum platypterum (Welw) Hutch \& Dalziel & Bush Willows & Combretaceae & Shrub & + & + & - & - \\
\hline Combretum racemosum $\mathrm{P}$. Beauv & Bush Willows & Combretaceae & Shrub & + & + & - & - \\
\hline Cynodon dactylon (L.) Pers. & Bermuda Grass & Poaceae & Grass & - & + & - & - \\
\hline Dryopteris pauciflora C.Chr. & Wood Fern & Dryopteridaceae & Herb & + & + & - & - \\
\hline Elaeis guineensis Jacq. & Oil Palm & Arecaceae & Tree & + & + & + & - \\
\hline Ficus sp L. & Fig & Moraceae & Tree & - & - & + & - \\
\hline Gnetum africana (L.) Welw. & “Okazi” (native name) & Gnetaceae & Climber & + & - & - & - \\
\hline Musanga cecropioides $\mathrm{R}$. Br. & African Corkwood Tree & Moraceae & Tree & + & + & - & - \\
\hline Nauclea diderrichii (De Wild. \& T. Durand Merrill.) & African Peach & Rubiaceae & Tree & - & - & + & - \\
\hline Newbouldia laevis (P. Beauv.) Seeman \& Bureau & “Ogilisi” (native name) & Bignoniaceae & Tree & + & - & - & - \\
\hline Nymphaea lotus L. & Water Lilly & Nymphaeaceae & $\begin{array}{l}\text { Aquatic } \\
\text { Herb }\end{array}$ & - & - & - & + \\
\hline Panicum maximum Jacq. & Guinea Grass & Poaceae & Grass & - & + & - & - \\
\hline Pistia stratiotes $\mathrm{L}$. & Water Lettuce & Araceae & $\begin{array}{c}\text { Aquatic } \\
\text { Herb }\end{array}$ & - & - & - & + \\
\hline Pterocarpus santalinoides L' her Ex DC & "Mututi” & Fabaceae & Tree & + & - & - & - \\
\hline Pueraria phaseoloides (Roxb.) Benth. & Tropical Kudzu & Fabaceae & Creeper & - & + & - & - \\
\hline Raphia hookeri G. Mann \& H. Wendl & Raphia Palm & Arecaceae & Tree & - & - & + & - \\
\hline Spondianthus preussii Engl. & Rat Poison (Efik) & Euphorbiaceae & Tree & - & - & + & - \\
\hline Terminalia superba Engl. \& Diels & White Afara & Combretaceae & Tree & + & + & - & - \\
\hline Trema guineensis (Shum \& Thonn.) Ficalho & Charcoal Tree & Ulmaceae & Tree & + & - & - & - \\
\hline
\end{tabular}

species were seen in only the Forest habitat, as compared to three species that were exclusively seen in Aquatic Habitat. Five (5) of twenty-seven plant species encountered were seen only in Fallow habitat. Similarly, the Riparian habitat also had five (5) species that were not seen in other habitats.

Among plant species that occurred in more than one habitats Elaeis guineensis Jacq. (Oil Palm tree) was present in three of the four habitats identified (i.e., excluding aquatic habitat). The oil palm trees were also seen within the homes- 
teads in all the communities surveyed. Seven out of the species were present in both forest and fallow lands. In the forest habitat, standing plants were seen, while only coppices at various stages of re-growths were sighted in the fallow lands. Only one species of plant, Anthocleista vogelii Planch., was common to both Forest and Riparian habitat. Only Alchornea cordifolia (Schum. \& Thonn.) Müll. Arg. occurred in both Fallow and Riparian habitats. Gnetum africana, which was seen planted near the homestead, was also encountered in the forest areas. Although Okazi is planted in homestead gardens, they grow very slowly and often do not establish or grow well when planted; hence they are mostly harvested from the wild [27].

\subsection{Local Uses of the Plant Species and Their Roles in Family Nutrition}

In sub-Saharan Africa, like most of the developing world, and increasingly even in the developed world, families utilise lands within the immediate vicinities of their houses to grow plants that provide food and nutrition to families [21]. The literature is replete with descriptions of the patterns, purposes, and nomenclatures for this practice, but their basic purpose is to provide social, spiritual, cultural and food resources to their owners [27]. In the poorer communities, such as in sub-Saharan Africa, the neglected plants in the homestead environment provide a form of income security in hard times, and as a source of food/nutrition and medicine at all times [5] [21]. The plant species found around the homesteads or within family compounds are deliberately left for food, medicinal, cultural or spiritual purposes [27], as source of materials for construction, tools, crafts or spiritual items. In addition, the homestead environment also supplies products that may be exchanged for petty cash to satisfy mundane family needs like buying soap or salt [27].

Most of the plant species found in the immediate vicinity of the homesteads are edible; some are cultivated for their medicinal or spiritual values, while others serve multiple purposes. Many of the species, such as Magnifera indica, Dacryodes edulis, Persea americana, Carica papaya, Chrysophyllum albidumand Ananas comosus, are grown mostly for their tasty fruits. The species Persea americana, locally called "English Pear", is cherished for its plum, creamy and tasty fruit pulp. Chrysophyllum albidum, known as Udara in local parlance, is grown for its tasty fruits with high commercial value that constitute a veritable source of rural family income [28]. These fruit trees are veritable sources of minerals and vitamins; some of them can supply the recommended dietary average, especially for children. Bitter leaf (Vernonia amygdalina), Ugu (Telferia occidentalis), Sweet Basil (Ocimum brasilicum), "Spinach" (Amaranthus hybridus) and Okazi (Gnetum africana) which are consumed vegetables and their leaves are used as soup condiments [29]. The leaves of Okazi plant are rich in aspartic acid, dietary fibre, proteins and vitamins. They are also rich sources of essential amino acids and minerals, including zinc, magnesium, calcium and 
iron [30]. Amaranthus hybridus is reported to supply the body with appreciable amounts of protein, vitamins and minerals [31].

The species Xanthosoma mafaffa (Cocoyam), Manihot esculentis (Cassava), Dioscorea spp (yams) and Artocarpus cuminis (Breadfruit), are valuable for their starchy corms, roots and fruits respectively. The cocoyam corms can be eaten boiled or, as it is the case in the study area, as thickening for making special native soups. Cassava is well known for its starchy roots and is locally processed into garri or fufu (loi-loi), but can also be industrially processed into starch, high grade syrup, flour, chips or flakes [32]. Locally, the breadfruit is processed into starchy foods, while the seeds are roasted and consumed as snacks, but they are staple foods in many places on the Pacific Islands [33]. Breadfruit can also be processed into various menus, bread flour or as nutritious feeds for broilers.

Although the Sugarcane (Saccharum officinarum) has known commercial value as source of sugar, they are not grown on commercial scale in the Niger Delta. Sugarcane are grown for consumption as snacks, hence only a few stands were seen around homesteads. Similarly, Cocos nucifera (coconut), are also not grown on any appreciable scale in the study area. They are mostly grown for aesthetics to decorate the landscape around homesteads, but their fruits are also consumed as snacks.

The bush mangos and guava trees are grown for their fruits, as well as for medicinal purposes. The pulp of the bush mango is consumed fresh, while the seeds (Ogbono) are used as thickener in preparing the Ogbono soup, a popular delicacy in the Niger Delta in particular and Nigeria in general. In southwest Nigeria, almost three-quarter of the population consume bush mango (Irvingia gabonensis) as fresh fruits or as soup condiments [22]. Scent leaves are used as vegetables for making soup and as spices for preparing pepper soup, while corn seeds are roasted or boiled and eaten as snack, or the raw seeds are used in making "akamu" (pap).

Some of the species have multiple uses: e.g., Vernonia amygdalina and Telferia occidentalis are also used for medicinal purposes, including serving as therapeutic supplementary nutrition for humans. Apart from its edible fruits, mango leaves are also used to treat several ailments including fevers, stomach upsets and lethargy. Pawpaw and bitter kola, are used to treat several ailments including fevers, stomach upset, lethargy and as laxatives. In addition to these species have commercial, medicinal or food values, some species also have spiritual/cultural values. For example, Dioscorea spp signify fertility and power and its harvest mark the beginning of the year in an annual ceremony called the New Yam festival. The tree Cola nitida produces the kola nuts (fruits), which are consumed as stimulants and constitute an important source of cash. Most importantly, kola nuts are respected and they play important socio-cultural roles in the lives of not only the Egi people but the entire Nigeria. No traditional ceremony such as wedding, child naming, funeral or even when visiting; is complete without offerings of kola nuts. 
The "bitter kola" (Garcina kola) seeds are harvested for consumption as stimulant or sold for cash income. Also, fruits of Garcinia kola are used as medicine against several ailments associated with respiratory, circulatory and digestive systems; while ground bitter cola seeds are used as snake repellents and to ward off evil spirits. Bitter kola is also taken on account of poverty or during periods of food shortages. For instance, in a rural location in Southwest Nigeria, $36.7 \%$ of the people confessed to have consumed bitter kola (Garcinia kola) as food during hard times [22].

\subsection{Species with Future Potentials in Ensuring Local Food Security}

Amongst the species identified within the study area, some are not only underutilised, but have great potentials for improving the food security situation in the study area, especially during period of distress occasioned by climate change. Apart from provision of food and medicine, the underutilised tree species can also contribute to climate mitigation by capturing atmospheric carbon dioxide in their biomass. The underutilised species found in the study area are shown in Table 3 and they include trees and shrubs, and most of them have multiples uses. However, this paper focuses on their uses as food and, their potentials to enhance the resilience of the poor rural inhabitants in the face of climate change thereby ensuring food and nutrition security.

Breadfruit (Artocarpus communis Forst) is an underutilised plant in Nigeria, but provides staple diet in many tropical countries, especially in south Pacific and the Caribbean [33]. The annual production of breadfruit in estimated to be about 10 million metric tonnes, which is less than one-tenth of Nigeria's potential production capacity [34]. It can be cultivated using root cuttings, but its yield is limited by lack of improved high yielding cultivars. The breadfruit is a high value, nutritive fruit that can be processed into diverse types of dishes [33]. The

Table 3. Locally underutilised species with great potentials for local food security.

\begin{tabular}{|c|c|c|}
\hline Scientific Name & Part Utilised & Potentials for Human Nutrition \\
\hline Annona muricata L. & Fruits (pulp) & Minerals, vitamins, antioxidants, fibre \\
\hline $\begin{array}{l}\text { Artocarpus communis } \\
\text { J.R. Forst. \& J.G.A. Forst }\end{array}$ & Fruits (seed, pulp) & $\begin{array}{l}\text { Carbohydrates, minerals, vitamins, } \\
\text { fats, antioxidants }\end{array}$ \\
\hline Chrysophyllum albidum G. Don & Fruits (seed, pulp) & Minerals, vitamins, fats, antioxidants \\
\hline Dacryodes edulis (G. Don) H.J. Lam & Fruits (pulp) & $\begin{array}{l}\text { Carbohydrates, minerals, fats, } \\
\text { antioxidants }\end{array}$ \\
\hline Irvingia gabonensis (O'Rorke) Baill & Fruits (seed, pulp) & $\begin{array}{l}\text { Proteins, minerals, vitamins, fats, } \\
\text { fibre, antioxidants }\end{array}$ \\
\hline Persea americana Mill. & Fruits (pulp) & $\begin{array}{l}\text { Minerals, vitamins, fats, proteins, } \\
\text { fibre, antioxidants }\end{array}$ \\
\hline Terminalia catappa L. & Fruits (seed, pulp) & Proteins, fats, vitamins, minerals \\
\hline Raphia hookeri G. Mann \& H. Wendl & Sap & $\begin{array}{c}\text { Carbohydrate, minerals, vitamins, } \\
\text { antioxidants }\end{array}$ \\
\hline
\end{tabular}


fruits can also be used to produce high quality composite flour that can be composited with wheat flour and used to make bread, biscuit and other confectionaries [34] [35].

Annona muricata, locally called sour-sop, is native to warmest parts of the Americas and it is widely distributed across the warm areas of the world including Nigeria. The fruits of Annona muricata are edible and can be processed into juice, fruit nectar, smoothes, candies, or used as flavouring for ice cream. Sour-sop is reported to contain relatively high concentrations of dietary minerals ( $\mathrm{Ca}, \mathrm{Mg}, \mathrm{K}, \mathrm{Fe}$ ), hence can provide human bodies with these minerals [36].

Chrysophyllum albidum trees produce tasty and fleshy fruits called "Udara" that are eaten as snack and it is very popular across the Niger Delta. Udara is reported to contain appreciable amounts of Vitamins (especially A and C), thiamine and riboflavin [28]. The fruit also contains extractable juice that can be used in making soft beverages, or fermented to produce wine and other alcoholic beverages [37]. In addition, seeds of Udara contain edible oils with high unsaturated fatty acids; the consumption of which can reduce the risk of heart diseases.

The fruit of Dacryodes edulis contains high amounts of energy-boosting carbohydrate and calcium, a nutrient needed for growth and maintenance of healthy bones and teeth. The pulp of Ube also contains fats and oils that can be used to substitute more expensive vegetable oils for both industrial and domestic use. The oil contained in Ube is known to contain linoleic acid, which helps to prevent vascular heart diseases [38]. Also, Dacryodes edulis contains antioxidants, which help to maintain good health and none of its constituents are known to be toxic to humans [38].

The pulp of Avocado fruits contains unsaturated fats and dietary fibre, vitamins, minerals and antioxidants [39]. Persia americana (Avocado pear) fruits are consumed for their creamy pulp, which is known to contain minerals such as iron, potassium, copper, magnesium, and manganese [39]. The pulp of Avocado fruits also contains appreciable concentrations of vitamins A, E and $\mathrm{K}$ [39]. Also, Avocado is reported to contain antioxidants in the form of flavonoids, which are important in the regulation and maintenance of the immune system. Consumption of the fruits can supply the body with mono-unsaturated fats, including oleic, palmitoleic and omega- 6 polyunsaturated, which helps prevent heart-related ailments [39]. In addition, to fat content, [39] reported that the Avocado fruit can supply appreciable amount of dietary fibre, which aids in the prevention of constipation.

Irvingia gabonensis is a multipurpose tree species that has received researchers' attention [40]. In the Niger delta, Irvingia fruits are often eaten fresh, while the seeds are extracted, dried, ground and used as condiment for making the Ogbono soup (derived from the local name of the tree species). The Ogbono fruit is reported to be nutritious as it contains appreciable amounts of minerals (calcium, magnesium, and sodium), vitamin C, amino acids, fats, and dietary fibre [41]. Although the fruits of Irvingia are consumed as fresh fruits or seeds extracted for soup making, they are underutilized in the Niger delta because the 
fruit can also be used to make wine, jelly, or jam, while the seeds can be processed into oil or margarine which enhances their availability offseason. The seeds can also be used in the formulation of animal feeds.

Raphia hookeri (Raffia palm) is a very important plant with multiple uses for construction and as source of food. The sap of Raphia, is extracted from the stem and consumed as fresh beverage (non alcoholic), or fermented to produce alcoholic palm wine or distilled to produce gin [42]. Ripe fruits of Raphia contain edible oils [43], while the trunks can also be manipulated to produce larvae of the beetle (Oryctes rhinoceros) and the weevil (Rhyncophorus pheonicis) that are prepared and served as nutritious delicacies [44].

Terminalia catappa trees were seen in compounds within the study area. The ripe fruits are often eaten by the local folks who eat the pulp, before breaking the seed coat to eat the nuts. The fruits are reported to contain high amounts of protein, with appreciable composition of the essential amino acids [45]. The seeds of Terminalia catappa are also reported to have high contents of oil with healthy fatty acid profile in accordance with dietary guidelines for edible oils [46].

\section{Conclusions}

Surveys of wild plants to determine their potentials as source of food are few, uncoordinated and irregular, as most studies report works on other uses of wild trees and not as veritable source of food. The livelihoods of the rural poor living in extreme deprivation are likely to worsen in the face of climate change. Notwithstanding the uncertainties facing the rural communities in the Niger Delta, the floral diversity around rural homesteads serves as sources of food (and family nutrition). This study discussed the roles of such plants as potential sources of food and their future potential in adapting to vagaries of climate change.

It is obvious that certain species do not only supply food and nutrition to the rural dwellers, they also have the potential to provide industrial raw materials to support the food and beverages industry. However, there is a need to improve on the methods or processes of exploiting the food potentials of the wild plants. Also, it is imperative to explore and develop varieties of menus possible for the identified plants with great future potentials as sources of food and nutrition. In addition, where possible and necessary, the rural poor should be incentivised to encourage the domestication and exploitation of the foods derivable from wild plant species.

\section{Acknowledgements}

The authors wish to acknowledge the kind assistance of Mr. John Ogazie in identifying most of the plant species reported in this paper.

\section{References}

[1] Sambo, B.E. (2014) Endangered, Neglected, Indigenous Resilient Crops: A Potential 
against Climate Change Impact for Sustainable Crop Productivity and Food Security. IOSR Journal of Agriculture and Veterinary Science, 7, 34-41. https://doi.org/10.9790/2380-07223441

[2] Stabinsky, D. and Ching, L. (2011) Ecological Agriculture, Climate Resilience and a Roadmap to Get There. TWN Environment \& Development Series No. 14, Third World Network, Penang. https://www.twn.my/title/end/pdf/end14.pdf

[3] Kiprutto, N., Rotich, L.K. and Riungu, G.K. (2015) Agriculture, Climate Change and Food Security. Open Access Library Journal, 2, 1 -7.

https://file.scirp.org/pdf/OALibJ_2016071511393047.pdf https://doi.org/10.4236/oalib.1101472

[4] Altieri, M.A., Nicholls C.I., Henao A. and Lana, M.A. (2015) Agroecology and the Design of Climate Change-Resilient Farming Systems. Agronomy for Sustainable Development, 35, 869-890.

https://link.springer.com/article/10.1007/s13593-015-0285-2

https://doi.org/10.1007/s13593-015-0285-2

[5] Ubom, R.M. (2010) Ethnobotany and Biodiversity Conservation in the Niger Delta, Nigeria. International Journal of Botany, 6, 310-322.

http://docsdrive.com/pdfs/ansinet/ijb/2010/310-322.pdf https://doi.org/10.3923/ijb.2010.310.322

[6] Sêdami, A.B., Naéssé, A.V., Pascal, G. and Firmin, A.D. (2017) Importance of Home Gardens in Rural Zone of the Municipality of Abomey-Calavi in South of Republic of Benin. Sustainable Agriculture Research, 6, 150-160.

http://www.ccsenet.org/journal/index.php/sar/article/view/71469/39026 https://doi.org/10.5539/sar.v6n4p150

[7] Chivenge, P., Mabhaudhi, T., Modi, A.T. and Mafongoya, P. (2015) The Potential Role of Neglected and Underutilized Crop Species as Future Crops under Water Scarce Conditions in Sub-Saharan Africa. International Journal of Environmental Research and Public Health, 12, 5685-5711.

https://www.ncbi.nlm.nih.gov/pmc/articles/PMC4483666/ https://doi.org/10.3390/ijerph120605685

[8] Ogunwasi, A.A. and Ibrahim, H.D. (2016) Industrial Potentials of Underutilized Plants in Nigeria. Journal Natural Science Research, 6, 20-28.

http://iiste.org/Journals/index.php/JNSR/article/view/29412

[9] Essien, B.A., Essien, J.B., Nwite, J.C., Ogbu, J.U., Okereke S.N. and Agunannah, M.U. (2013) Contribution of Plant Species in Homestead Farms, to Food Security and Sustainability in Ebonyi State-South Eastern Nigeria. African Journal of Plant Science, 7, 317-324.

http://citeseerx.ist.psu.edu/viewdoc/download?doi=10.1.1.898.9653\&rep=rep1\&type $=\mathrm{pdf}$ https://doi.org/10.5897/AJPS12.071

[10] Hamadina, M.K., Otobotekere, D. and Anyanwu, D.I. (2007) Impact Assessment and Biodiversity Considerations in Nigeria: A Case Study of Niger Delta University Campus Project on Wildlife in Nun River Forest Reserve. Management of Environmental Quality: An International Journal, 18, 179-197. http://www.emeraldinsight.com/doi/abs/10.1108/14777830710725849 https://doi.org/10.1108/14777830710725849

[11] Okiwelu, S.N., Ewurum, N. and Noutcha, M.A.E. (2009) Wildlife Harvesting and Bushmeat Trade in Rivers State, Nigeria: Species Composition, Seasonal Abundance and Cost. Scientia Africana, 8, $1-8$.

https://www.researchgate.net/publication/269985096_Wildlife_harvesting_and_bus 
hmeat_trade_in_Rivers_State_Nigeria_I_species_composition_seasonal_abundance and_cost

[12] Short, K.C. and Stäuble, A.J. (1965) Outline of Geology of Niger Delta. American Association of Petroleum Geology Bulletin, 51, $761-779$.

http://archives.datapages.com/data/bulletns/1965-67/data/pg/0051/0005/0750/0761. $\underline{\mathrm{htm} \text { ?doi=10.1306\%2F5D25C0CF-16C1-11D7-8645000102C1865D }}$

[13] Mmom, P.C. and Aifesehi, P.E. (2013) Impact of the 2012 Flood on Water Quality and Rural Livelihood in the Orashi Province of the Niger Delta, Nigeria. Journal of Geography and Geology, 5, 216-225.

http://www.ccsenet.org/journal/index.php/jgg/article/viewFile/29114/17696 https://doi.org/10.5539/jgg.v5n3p216

[14] Intergovernmental Panel on Climate Change (2014) Climate Change 2014: Synthesis Report. Contribution of Working Groups I, II and III to the Fifth Assessment Report of the Intergovernmental Panel on Climate Change Core Writing Team, In: Pachauri, R.K. and Meyer, L.A., Eds., IPCC, Geneva, 151.

https://www.ipcc.ch/pdf/assessment-report/ar5/syr/SYR_AR5_FINAL_full_wcover. pdf

[15] Mwaniki, F.N., Gichuki, C., Mwangi, M., Mburia, P. and Wandago, B. (2017) Addressing Challenges in Communicating Adaptation Practices to Smallholder Farmers in Kenya through a Radio Intervention. Journal Agriculture and Environment for International Development, 111, 279-322.

http://www.iao.florence.it/ojs/index.php/JAEID/article/view/589

[16] Enemugwem, J.H. (2009) The Development of the Niger Delta of Nigeria, 1900-1966. Journal of Sustainable Development in Africa, 10, 162-178.

[17] Mgbada, J.U., Ohajianya, D.O. and Nzeh, E.C. (2016) Sustainable Agricultural Practices and Its Determinants in South-East Nigeria. Journal of Advanced Agricultural Technologies, 3, 170-174.

http://www.joaat.com/uploadfile/2016/1205/20161205032837282.pdf

[18] Emam, E.A. (2015) Gas Flaring in Industry: An Overview. Petroleum and Coal, 57, 532-555. http://large.stanford.edu/courses/2016/ph240/miller1/docs/emam.pdf

[19] Biogeochem Associates Ltd. (2015) Environmental Evaluation Study. Final Report.

[20] Hamadina, M.K. and Anyanwu, D.I. (2012) A Cursory Review of the Consequences of Human Activities and Land-Use Changes in the Niger Delta. Research Journal of Environmental and Earth Sciences, 4, 597-604. http://maxwellsci.com/jp/abstract.php?jid=RJEES\&no=206\&abs=13

[21] Nwaneke, P.K. and Chude, V.O. (2017) Are the Homestead Gardens a Possible Solution to Combating Malnutrition in Nigeria? European Journal of Nutrition and Food Safety, 7, 199-208. http://www.sciencedomain.org/abstract/21293 https://doi.org/10.9734/EJNFS/2017/36520

[22] Osewa, S.O., Alamu, O., Adetiloye, I.S., Olubiyi, M.R. and Abidogun, E.A. (2013) Use of Some Neglected and Underutilized Plant Species among Rural Dwellers in Akinyele Local Government Area of Oyo State. Greener Journal of Agricultural Science, 3, 817-822.

http://www.gjournals.org/GJAS/GJAS\%20Pdf/2013/December/060913821\%20Osew a\%20et\%20al.pdf

[23] Hutchinson, J. and Dalziel, J.M. (1958) Flora of West Tropical Africa. In: Keay, R.W.J., Ed., 2nd Edition, Vol. 1. Part 2, Published on Behalf of the Governments of Nigeria, Ghana, Sierra Leone \& The Gambia by Crown Agents for Overseas Governments and Administrations, Millbank, London. 
[24] Hutchinson, J. and Dalziel, J.M. (1963) Flora of West Tropical Africa. In: Hepper, F.N., Ed., 2nd Edition, Vol. 11, 10th October, Published on Behalf of the Governments of Nigeria, Ghana, Sierra Leone and The Gambia by Crown Agents for Overseas Governments and Administrations, Millbank, London.

[25] Hutchinson, J. and Dalziel, J.M. (1968) Flora of West Tropical Africa. In: Hepper, F.N., Ed., 2nd Edition, Vol. 111, Part 1, 28th August, Published on Behalf of the Governments of Nigeria Ghana, Sierra Leone \& The Gambia by Crown Agents for Overseas Governments and Administrations, Millbank, London.

[26] Hutchinson, J. and Dalziel, J.M. (1972) Flora of West Tropical Africa. In: Hepper, F.N., Ed., 2nd Edition, Vol. 111, Part 2, 2nd May, Published on Behalf of the Governments of Nigeria, Ghana, Sierra Leone \& The Gambia by Crown Agents for Overseas Governments and Administrations, Millbank, London.

[27] Galhena, D.H., Freed, R. and Maredia, K.M. (2013) Home Gardens: A Promising Approach to Enhance Household Food Security and Wellbeing. Agriculture \& Food Security, 2, 1-13.

[28] Ureigho, U.N. and Ekeke, B.A. (2010) Nutrient Values of Chrysophyllum albidum Linn African Star Apple as a Domestic Income Plantation Species. International Multi-Disciplinary Journal, 4, 50-56.

https://www.ajol.info/index.php/afrrev/article/viewFile/58288/46639 https://doi.org/10.4314/afrrev.v4i2.58288

[29] Belewu, M.A., Olatunde, O.A. and Giwa, T.A. (2009) Underutilized Medicinal Plants and Spices: Chemical Composition and Phytochemical Properties. Journal of Medicinal Plants Research, 3, 1099-1103.

http://www.academicjournals.org/article/article1380526435_Belewu\%20et\%20al.pdf

[30] Ndomou, M., Mezajoug, K.L.B and Tchiegang, C. (2014) Physico-Chemical Properties of Leaves of Gnetum africanum (L.) and Gnetum bucholzianum (L.) (Gnetaceae) from Cameroon. American Journal of Research Communication, 2, 101-112. http://www.usa-journals.com/wp-content/uploads/2014/11/Ndomou_Vol212.pdf

[31] Kadiri, O. and Olawoye, B. (2012) Underutilized Indigenous Vegetables (UIV) in Nigeria: A Rich Source of Nutrient and Antioxidants-A Review. Annals. Food Science and Technology, 6, 236-247. http://www.sciepub.com/reference/207795

[32] Adeniji, T.A. (2013) Review of Cassava and Wheat Flour Composite in Bread Making: Prospects for Industrial Application. The African Journal of Plant Science and Biotechnology, 7, 1-8.

http://www.globalsciencebooks.info/Online/GSBOnline/images/2013/AJPSB_7(1)/ AJPSB_7(1)1-8o.pdf

[33] Tijani, A.O., Oke, E.K., Bakare, H.A. and Tayo, T.R. (2017) Quality Evaluation of Instant Noodles Produced from Composite Breadfruit Flour. Researcher, 9, 21 -26. http://www.sciencepub.net/researcher/research090117/03_31564rsj090117_21_26.p df

[34] Bakare, A.H, Osundahunsi, O.F. and Olusanya, J.O. (2016) Rheological, Baking, and Sensory Properties of Composite Bread Dough with Breadfruit (Artocarpus communis Forst) and Wheat Flours. Food Science and Nutrition, 4, 573-587.

https://www.ncbi.nlm.nih.gov/pmc/articles/PMC4930501/ https://doi.org/10.1002/fsn3.321

[35] Ajani, A.O., Fasoyiro, S.B., Arowora, K.A., Ajani, O.O., Popoola, C.A. and Zaka, K.O. (2016) Functional Properties of Composite Flour Made from Wheat and Breadfruit. Applied Tropical Agriculture, 21, 89-93.

[36] Moghadamtousi, S.Z., Fadaeinasab, M., Nikzad, S., Mohan, G., Ali, H.M. and Kadir, 
H.A. (2015) Annona muricata (Annonaceae): A Review of Its Traditional Uses, Isolated Acetogenins and Biological Activities. International Journal of Molecular Science, 16, 15625-15658.

https://www.ncbi.nlm.nih.gov/pmc/articles/PMC4519917/

https://doi.org/10.3390/ijms160715625

[37] Ajewole, K. and Adeyeye, A. (1991) Seed Oil of White Star Apple (Chrysophyllum albidum) Physiochemical Characteristics and Fatty Acid Composition. Journal of Science, Food and Agriculture, 54, 313-315.

http://onlinelibrary.wiley.com/doi/10.1002/jsfa.2740540219/abstract https://doi.org/10.1002/jsfa.2740540219

[38] Ajibesin, K.K. (2011) Dacryodes edulis (G. Don) H. J. Lam: A Review on Its Medicinal, Phytochemical and Economic Properties. Research Journal of Medicinal Plants, 5, 32-34. http://www.scialert.net/fulltext/?doi=rjmp.2011.32.41\&org=10

[39] Talabi, J.Y., Osukoya, O.A., Ajayi, O.O. and Adegoke, G.O. (2016) Nutritional and Antinutritional Compositions of Processed Avocado (Persea americana Mill) Seeds. Asian Journal of Plant Science and Research, 6, 6-12.

http://www.imedpub.com/articles/nutritional-and-antinutritional-compositions-ofprocessed-avocado-persea-americana-mill-seeds.pdf

[40] Ayuka, E.T., Duguma, B., Steve Franze, S., Kengue, J., Mollet, M., Tiki-Manga, T. and Pauline Zenkeng, P. (1999) Uses, Management and Economic Potential of Irvingia gabonensis in the Humid Lowlands of Cameroon. Forest Ecology and Management, 113, 1-9.

https://www.sciencedirect.com/science/article/pii/S0378112798003235 https://doi.org/10.1016/S0378-1127(98)00323-5

[41] Ayivor, J.E., Debrah, S.K., Nuviadenu, C. and Forson, A. (2011) Evaluation of Elemental Contents of Wild Mango (Irvingia gabonensis) Fruit in Ghana. Advance Journal of Food Science and Technology, 3, 381-384.

http://maxwellsci.com/print/ajfst/v3-381-385.pdf

[42] Martinez, M.C., Depinto, G.L. and Rivas, C. (1992) Composition of Acacia macracantha Gum Exudates. Phytochemistry, 31, 535-536.

https://www.sciencedirect.com/science/article/pii/003194229290033M

https://doi.org/10.1016/0031-9422(92)90033-M

[43] Otedoh, M.O. (1990) Sweet Raffia Palm Wine. The Nigerian Field, 5, 59-64.

[44] Onyeike, E.N., Ayalogu, E.O. and Okaraonye, C.C. (2005) Nutritive Value of the Larvae of Raphia Palm Beetle (Oryctes rhinoceros) and Weevil (Rhyncophorus pheonicis). Journal Science, Food and Agriculture, 85, 1822-1828.

http://onlinelibrary.wiley.com/doi/10.1002/jsfa.2054/abstract https://doi.org/10.1002/jsfa.2054

[45] Ezeokonkwo, C.A. and Dodson, W.L. (2004) The Potential of Terminalia catappa (Tropical Almond) Seed as a Source of Dietary Protein. Journal of Food Quality, 27, 207-219.

http://onlinelibrary.wiley.com/doi/10.1111/j.1745-4557.2004.tb00650.x/epdf https://doi.org/10.1111/j.1745-4557.2004.tb00650.x

[46] Supatcha, J., Ho, C., Chavasit, V., Pan, M., Chittrakorn, S., Ruttarattanamongkol, K. and Weerawatanakorn, M. (2015) Physicochemical Properties of Terminalia catappa Seed Oil as a Novel Dietary Lipid Source. Journal of Food and Drug Analysis, 23, $201-209$.

https://www.sciencedirect.com/science/article/pii/S1021949814000994

https://doi.org/10.1016/j.jfda.2014.06.007 